\title{
Solute Carrier Family 12 Member 7
}

National Cancer Institute

\section{Source}

National Cancer Institute. Solute Carrier Family 12 Member 7. NCI Thesaurus. Code C124991.

Solute carrier family 12 member $7(1083 \mathrm{aa}, \sim 119 \mathrm{kDa})$ is encoded by the human SLC12A7 gene. This protein plays a role in transmembrane transport of both potassium and calcium ions. 